\title{
Effect of New Synthesized Copper Complex of 4-azomalononitrile antipyrine with Superoxide Dismutase Activity on Ehrlich Ascites Carcinoma in Mice
}

\author{
Omali Y. El-Khawaga ${ }^{1}$ and I. H. El-sayed ${ }^{2}$ \\ ${ }^{1}$ Chemistry Department, Faculty of Science, Mansoura University, \\ ${ }^{2}$ Molecular Biology Department, Genetic Engineering and \\ Biotechnology Institute, Minufia University, Sadat City, Egypt.
}

\begin{abstract}
Background: A number of $\mathrm{Cu}(\mathrm{II})$ chelate complexes that exhibit cytotoxic activity through cell apoptosis or enzyme inhibition was reported to have numerous biologic activities including antibacterial, antifungal, antiviral and anti-tumor properties. The present work aimed to study the effect of new synthesized $\mathrm{Cu}$ complex of 4azomalononitrile antipyrine $\left[\mathrm{CuL}(\mathrm{OH})\left(\mathrm{ClO}_{4}\right)\right]$ which exhibits superoxide dismutase (SOD)-mimetic activity on tumor in mice induced by Ehrlich ascites carcinoma (EAC) cell line. Results: The administration of $10 \mathrm{mg} / \mathrm{kg}$ body weight $\left[\mathrm{CuL}(\mathrm{OH})\left(\mathrm{ClO}_{4}\right)\right] 24$ hours after intraperitoneal injection of EAC, effectively inhibited tumor growth and the proliferation of EAC cells. Cu complex ameliorated the increase in serum aspartate transaminase (AST) and alanine transaminase (ALT) activities after implantation of EAC cells. On the other hand, the level of creatinine was increased. Moreover, $\mathrm{Cu}$ complex of 4-azomalononitrile antipyrine significantly improved the hepatic and erythrocytes SOD and GRX activities. The glutathione content of hepatic tissues and erythrocytes was restored in EAC tumor bearing mice. Furthermore, it also, inhibited the formation of nitric oxide and lipid peroxidation products (thiobarbituric acid reactive substance, TBARS) in EAC tumor bearing mice. This effect was associated with inhibition of cell cycle progression and induction of apoptosis. Administration of $\left[\mathrm{CuL}(\mathrm{OH})\left(\mathrm{ClO}_{4}\right)\right]$ complex 24 hours after injection of EAC for 3 weeks arrested cells in G0/G1 phase and resulted in a decrease in the viability. Conclusions: $\mathrm{Cu}$ complex $\left[\mathrm{CuL}(\mathrm{OH})\left(\mathrm{ClO}_{4}\right)\right]$ has a strong inhibitory activity against growth of tumors. The anti-tumor mechanism may be mediated by preventing oxidative damage and induction of apoptosis.
\end{abstract}

Keywords: Antitumor activity; Copper complex; Oxidative stress; Flow cytometry; Ehrlich ascites carcinoma cells

\section{INTRODUCTION}

It is well known that metal ions have a great importance in biological systems where many enzymes, hormones and antibiotics contain metal ions in their structures and their actions are inhibited if the metal ion is lost. The relationship between the antioxidant systems and growth of malignant cells is a feature observed in several studies. However, low activity of antioxidant system was 
found in cancer cases (Anand et al., 2008) ${ }^{(1)}$.

The reactive oxygen species produced in cells include hydrogen peroxide $\left(\mathrm{H}_{2} \mathrm{O}_{2}\right)$, hypochlorous acid $(\mathrm{HOCl})$, and free radicals such as the hydroxyl radical $\left(\mathrm{OH}^{-}\right)$and the superoxide anion $\left(\mathrm{O}_{2}^{-}\right)$(Valko et al., 2006) ${ }^{(2)}$. The hydroxyl radical is particularly unstable and will react rapidly and non-specifically with most biological molecules. This species is produced from hydrogen peroxide in metal-catalyzed redox reactions such as the Fenton reaction (Valko et al., 2005) ${ }^{(3)}$. These oxidants can damage cells by starting chemical chain reactions such as lipid peroxidation, or by oxidizing DNA or proteins (Lecour et al., 2006) ${ }^{(4)}$. Damage to DNA can cause mutations and possibly cancer, if not reversed by DNA repair mechanisms (Cesaratto et al., 2004) ${ }^{(5)}$ while damage to proteins causes enzyme inhibition, denaturation and protein degradation (Kc et al., 2006) ${ }^{(6)}$.

Superoxide dismutase (SOD) is an enzyme currently thought to provide a defense against toxic products of oxygen metabolism and to be necessary in all oxygen utilizing cells. SOD is the antioxidant enzyme that catalyzes the dismutation of $\mathrm{O}^{2 \cdot-}$ to $\mathrm{O}^{2}$ and to the less-reactive species $\mathrm{H}_{2} \mathrm{O}_{2}$ (Barondeau et al., 2004) ${ }^{(7)}$. Two forms of SOD have been found in the cells of higher animals. A copper and zinc-containing form (CuZn.SOD) is found largely in the cytosol and a manganese containing form (Mn.SOD) is found primarily in the mitochondria (Landis and Tower, 2005) ${ }^{(8)}$. Both forms of the enzyme are generally found in all normal cells of higher animals with exception of the red cell which do not contain mitochondria and thus have no Mn.SOD (Behrend et al., 2003) ${ }^{(9)}$. Since DNA is a potent target of cytostatic drugs, the effect of copper compounds on DNA functionality is very important. The ability of $\mathrm{Cu}$ (II) complexes to bind to DNA and exhibit nuclease activity in the presence of reducing agents is well established (Wang et al., 2010) ${ }^{(10)}$.

An antioxidant is a molecule capable of inhibiting the oxidation of other molecules. Oxidation is a chemical reaction that transfers electrons from a substance to an oxidizing agent leading to formation of free radicals. In turn, these radicals can start chain reactions that damage cells. Antioxidants terminate these chain reactions by removing free radical intermediates, and inhibit other oxidation reactions (Sies, 1997) ${ }^{(11)}$.

Copper exhibits considerable biochemical action either as an essential trace metal or as a constituent of various exogenously administered compounds in humans (Suntres and Lui, 2006) ${ }^{(12)}$. In its former role it is bound to ceruloplasmin, albumin, and other proteins, while in its latter it is bound to ligands of various types forming complexes that interact with biomolecules, mainly proteins and nucleic acids (Brewer, 2009) ${ }^{(\mathbf{1 3})}$. It is an essential component of several endogenous antioxidant enzymes, and that free radicals have been proposed to play a role in the process of carcinogenesis, the effects of dietary copper levels on the development of cancer have been investigated (Daniel et al., 2004) ${ }^{(14)}$. Although copper 
homeostatic mechanisms play an important role in the prevention of copper toxicity, exposure to excessive levels of copper can result in a number of adverse health effects including liver and kidney damage, anemia, immunotoxicity, and developmental toxicity (Bonham et al. 2002) ${ }^{(15)}$. It was shown that copper proteins are associated with metabolic changes in cancer cells (Tisato et al., 2010) ${ }^{(16)}$ and most importantly play a significant role in angiogenesis by stimulating proliferation and migration of human endothelial cells. In this context, we examined the inhibitory activities of new synthesized $\mathrm{Cu}$ complex with 4azomalononitrile antipyrine $\left[\mathrm{CuL}(\mathrm{OH})\left(\mathrm{ClO}_{4}\right)\right]$ which exhibits superoxide dismutase (SOD)-mimetic activity against Ehrlich carcinoma cells implanted intraperitoneally in female mice.

\section{MATERIALS \& METHODS}

\section{Materials:}

All chemicals used in the present study were of analytical grade and were purchased from Sigma Chemical Co. (St. Louis, MO, USA). Diagnostic kits for assaying alanine transaminase (ALT); aspartate transaminase (AST) and creatinine were purchased from Diamond Diagnostics Company, Cairo, Egypt.

$$
\text { The copper perchlorate }
$$

$\left[\mathrm{CuL}(\mathrm{OH})\left(\mathrm{ClO}_{4}\right)\right]$ Complex was prepared according to methods of ElSaid et al.(2000) ${ }^{(17)}$.

Experimental animals:

All experiments were performed using adult female Swiss albino mice, with an average body weight of $25 \mathrm{~g}$ purchased from Theodore Bilharz Research Institute, Giza, Egypt. The mice were housed in steel mech cage and provided with commercial standard diet and tap water ad libitum. A total of 40 Swiss albino mice were divided into 4 groups, 10 mice each, according to the following scheme: group 1: control (untreated) mice; group 2: mice injected by $10 \mathrm{mg} / \mathrm{kg}$ copper complex intraperitoneally (i.p.) for three weeks, 3 times/week; group 3: mice inoculated intraperitoneally with $1 \times 10^{6}$ EAC tumor cells; group 4: mice were treated by $10 \mathrm{mg} / \mathrm{kg} \mathrm{Cu}$ complex after 24 hours of implantation of $1 \times 10^{6}$ EAC tumor cells. After two days of the last treatment, the animals were sacrificed by decapitation. Ascetic fluid, blood and livers were immediately obtained after the animals were sacrificed. Blood samples allowed to clot for 10 to 15 minutes, centrifuged and the serum was separated and then the erythrocytes were washed with saline solution three times and hemolysed by diluting with deionized water. The serum and hemolysate were kept in $70^{\circ} \mathrm{C}$. An accurately weighed piece of each of livers was homogenized in ice-cold $0.9 \%$ saline using a Teflon pestle connected to a homogenizer motor. The homogenates were adjusted at a concentration of $5 \%$ $(\mathrm{w} / \mathrm{v})$, centrifuged at $5000 \mathrm{rpm}$ for 30 minutes at $4^{\circ} \mathrm{C}$ to remove cell debris and nuclei. The resulting supernatant was used for biochemical analysis.

\section{Determination of viability in vitro:}

Seven days after implantation, Ehrlich ascites carcinoma cells were harvested, and viability of living cells using Trypan Blue $(0.23 \%)$ was 
checked according to the method of Boyse et al. (1964) ${ }^{(18)}$.

Determination of survival time:

Two groups of mice ( $n=12$ each) were implanted with Ehrlich carcinoma cells. One of them was daily treated intraperitoneally by 10 $\mathrm{mg} / \mathrm{kg}$ body weight $\mathrm{Cu}$ complex. Each time $\mathrm{Cu}$ complex was given between 11.00 and 11.30 AM during the day, firstly to avoid circadian interference and secondly, to increase its level at the time $\mathrm{Cu}$ complex level in circulation is minimal (Tapiero et al., 2003) ${ }^{(19)}$.

\section{Enzyme assay:}

Reduced glutathione (GSH) content was estimated as described by Beutler et al. (1963) ${ }^{(\mathbf{2 0 )}}$. ALT and AST activities and creatinine level were measured using Diagnostic kits (Diamond Diagnostics Company, Cairo, Egypt) according to the manufacturer' $\mathrm{s}$ instructions. Glutathione peroxidase (GSH-PX) was measured by the method of Beulter (1975) (21). Superoxide dismutase activity (SOD) was assayed as described by Nishikimi et al. (1972) ${ }^{(22)}$. Nitric oxide (NO) was assayed by the method of Schmidt et al. (1995) ${ }^{(23)}$, Thiobarbituric acid reactive substances (TBARS), an index of lipid peroxidation, was determined as described by Satoh (1978) ${ }^{(\mathbf{2 4})}$. Protein in the homogenates was estimated by the method of Lowry et al.(1951) ${ }^{(25)}$. Hemoglobin $(\mathrm{Hb})$ contents of the samples were measured as described by Wintrobe et al. (1965) ${ }^{(26)}$.

Flow Cytometry:

Single cell suspension was prepared from fresh biopsy samples in RPMI-1640 medium. Cells were permeabilized with Triton X-100 followed by staining using propidium iodide as a DNA- specific fluorochrome. Flow cytometric analysis was performed on FACS Calibur Flow Cytometer, Becton Dickinson, Heidelberg, Germany; excitation of fluorescence occurred at $488 \mathrm{~nm}$ (15 mw air cooled argon ion lazer) and optimized for linear fluorescence single detection with the use of fluorochrome-labeled microspheres (DNA Checked Beads, Coulter Corp.), Chicken red blood cells and human peripheral blood. Non-linear events were excluded from flow cytometric DNA analysis by grading on histogram of $90^{\circ}$ light scatter versus forward angle light scatter. Data analysis was performed with DNA analysis software program using a linear S-fit method for cell cycle kinetic analysis. A minimum of 5000 cells (range, 5000-25000) cells; mean, 15000 were analyzed for each case (Baisch et al., 1975) ${ }^{(27)}$. Interpretation of DNA histograms was analyzed using cytoloic software (Coulter Corp.).

Statistical Analysis:

The results are expressed as mean \pm SD. Statistical analysis was performed according to the method of Murray (1982) (28). Data were analyzed using unpaired student's ttest. $\quad \mathrm{P}$ values of $<0.05$ were considered to be statistically significant

\section{RESULTS}

SOD-mimetic activity of $\mathrm{Cu}$ complex of 4-azomalononitrile antipyrine was measured as percent of inhibition of reduction of nitro blue tetrazolium (NBT). As shown in 
figure (1), the copper complex showed higher SOD-like activity at dose dependent manner and reached to maximum inhibition of NBT reduction $(86 \%)$ at $200 \mu \mathrm{M}$ concentration of this complex. Fig. 2 shows the effect of different concentrations of $\mathrm{CuL}(\mathrm{OH})\left(\mathrm{ClO}_{4}\right)$ $(25,50,100$ and $200 \mu$ mole $)$ on the viability of EAC cells in vitro. It is observed that there was gradual decrease in the viability with increasing the $\mathrm{Cu}$ complex concentration in a dose dependent type. Fig. 3 shows the effect of daily treatment with $\mathrm{CuL}(\mathrm{OH})\left(\mathrm{ClO}_{4}\right)$ complex on the survival time and the percentage of survivals were followed for 30 days. An increase in the survival time of $\mathrm{CuL}(\mathrm{OH})\left(\mathrm{ClO}_{4}\right)$ complex treated mice compared to untreated group. Serum transaminases (ALT and AST) activity and creatinine level in different studied groups are presented in table 1. A significant reduction in the activities of AST and ALT in tumor bearing mice treated with $\mathrm{CuL}(\mathrm{OH})\left(\mathrm{ClO}_{4}\right)$ complex compared to untreated mice group, whereas serum level of creatinine was significantly elevated after treatment by $\mathrm{Cu}$ complex compared to untreated mice group. Superoxide dismutase (SOD) and GPX activities of liver tissues and erythrocytes are shown in tables (12). SOD, GPX activities were significantly increased by administering tumor bearing mice group by $10 \mathrm{mg} / \mathrm{kg} \mathrm{Cu}$ complex. Moreover, the level of GSH of liver tissues and erythrocytes significantly increased at respective doses of 10 $\mathrm{mg} / \mathrm{kg} \mathrm{Cu}$ complex. The effect of intraperitoneal administration of $\mathrm{CuL}(\mathrm{OH})\left(\mathrm{ClO}_{4}\right)$ complex on hepatic nitric oxide (NO) level is presented in table 2. A significant increase was observed in the level of hepatic nitric oxide in tumor bearing mice group. This level was suppressed in EACbearing mice treated by $\mathrm{CuL}(\mathrm{OH})\left(\mathrm{ClO}_{4}\right) \quad$ complex. A significant decrease in the level of TBARS was obtained in the liver tissues and erythrocytes of tumor bearing mice group after treatment by $10 \mathrm{mg} / \mathrm{kg}$ of $\mathrm{Cu}$ complex of 4azomalononitrile antipyrine. Fig.4 shows EAC cells proliferation measured by flow cytometer to analyze the component of the cell cycle. It is evident that EAC cells from $\mathrm{Cu}$ complex treated mice exhibited significantly higher G0/G1\% and lower S-phase and $\mathrm{G} 2 / \mathrm{M} \%$ as compared with those obtained from untreated mice. In addition, DNA index which indicates aneuploidy cells is significantly lower in EAC cells aspirated from $\mathrm{Cu}$ complex treated mice than cells obtained from untreated mice. $\mathrm{G} 2 / \mathrm{G} 1 \%$ is insignificantly different in both groups. 


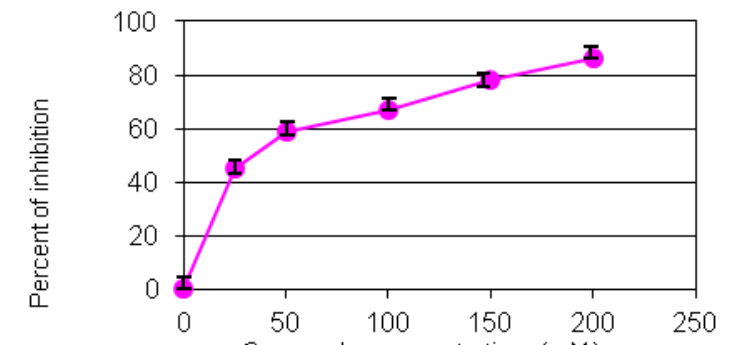

Fig .(1) Sucomplex concentrations (mM) $\mathrm{Cu}$ complex of 4-azomalononitrile antipyrine. $V$ alues are mean plus standared deviation $n=6$ ). $P \square$

0.05 compared with the values without complexes.

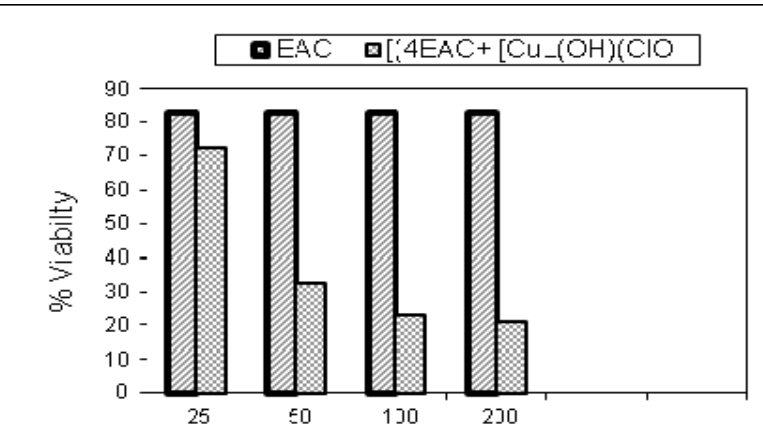

Fig. (2): Cuffecomp of cynfertrationsumole $\left.\left[\mathrm{CuL}(\mathrm{OH}), \mathrm{ClO}_{4}\right)\right]$ complex on the percentage $\checkmark$ abilizy of EAC cells in vitrio

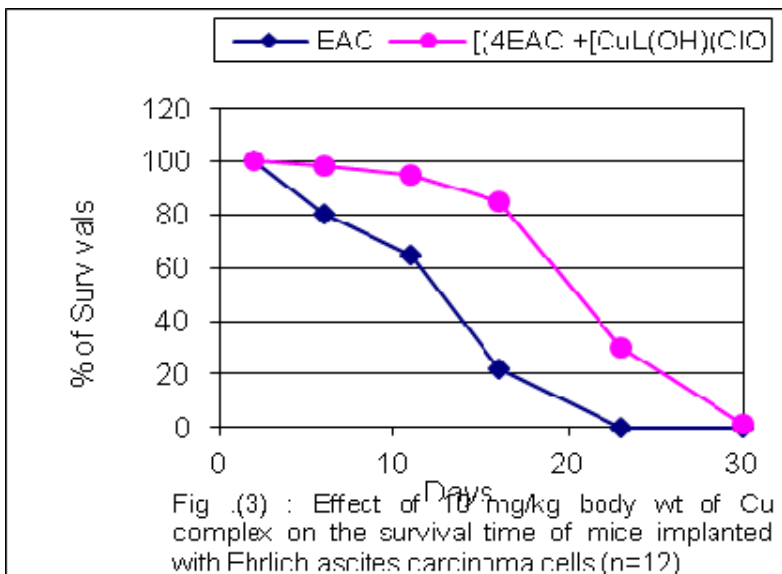


A
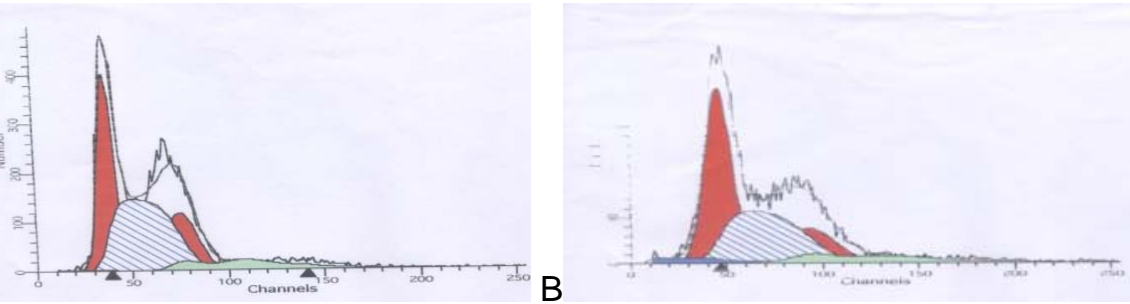

Fig. 4: DNA histogram of EAC cells: A: histogram of EAC cells isolated without treatment, B: histogram of EAC cells isolated from $\left[\mathrm{CuL}(\mathrm{OH})\left(\mathrm{ClO}_{4}\right)\right]$ - treated mice

Table 1: Liver and Kidney Function tests in different groups studied

\begin{tabular}{|l|l|l|l|l|}
\hline Parameter & $\begin{array}{l}\text { Control } \\
\text { (healthy } \\
\text { mice) }\end{array}$ & $\begin{array}{l}{[\mathrm{CuL}(\mathrm{OH})(\mathrm{ClO}} \\
\text { 4)]-treated mice }\end{array}$ & $\begin{array}{l}\text { EAC } \\
\text { bearing } \\
\text { mice }\end{array}$ & $\begin{array}{l}{[\mathrm{CuL}(\mathrm{OH})(\mathrm{ClO})]-} \\
\text { treated EAC bearing } \\
\text { mice }\end{array}$ \\
\hline ALT (U/L) & $21.44 \pm 0.62$ & $42.74 \pm 0.33^{*}$ & $151.88 \pm 0.1$ & $107.30 \pm 0.22+$ \\
\hline AST (U/L) & $30.00 \pm 0.16$ & $23.40 \pm 0.78^{*}$ & $192.84 \pm 0.2$ & $119.48 \pm 0.40+$ \\
\hline Creatinine (mg/dl) & $0.26 \pm 0.04$ & $0.24 \pm 0.03^{*}$ & $0.22 \pm 0.01$ & $0.23 \pm 0.02+$ \\
\hline Hb, g./dl & $14.51 \pm 0.18$ & $13.43 \pm 0.19^{*}$ & $10.24 \pm 0.21$ & $11.453 \pm 0.27+$ \\
\hline
\end{tabular}

Results are expressed as mean \pm SD of mice $(n=10)$. *Significant $(\mathrm{p}>0.05)$ compared to normal control group. + Significant $(\mathrm{p}>0.05)$ compared to tumor- bearing group

Table 2: Mean and standard deviation of SOD and GPX activities as well as NO,

MDA and GSH contents in liver of different groups studied.

\begin{tabular}{|l|l|l|l|l|}
\hline Parameter & $\begin{array}{l}\text { Control } \\
\text { (healthy } \\
\text { mice) }\end{array}$ & $\begin{array}{l}{\left[\mathbf{C u L}(\mathbf{O H})\left(\mathbf{C l O}_{4}\right)\right.} \\
\text { l-treated mice }\end{array}$ & $\begin{array}{l}\text { EAC bearing } \\
\text { mice }\end{array}$ & $\begin{array}{l}{\left[\mathbf{C u L}(\mathbf{O H})\left(\mathrm{ClO}_{4}\right)\right]_{-}} \\
\text {treated EAC } \\
\text { bearing mice }\end{array}$ \\
\hline SOD $(\mathrm{U} / \mathrm{mg}$ protein $)$ & $474.35 \pm$ & $480.55 \pm 0.80^{*}$ & $292.94 \pm 0.42$ & $539.06 \pm 0.76+$ \\
\hline $\mathrm{GPX}(\mathrm{U} / \mathrm{mg}$ protein $)$ & $43.82 \pm 0.52$ & $51.00 \pm 8.09^{*}$ & $36.17 \pm 2.01$ & $63.83 \pm 1.92+$ \\
\hline $\mathrm{GSH}(\mu \mathrm{mol} / \mathrm{mg}$ & $10.62 \pm 0.23$ & $13.00 \pm 0.27^{*}$ & $7.31 \pm 0.81$ & $15.04 \pm 0.30+$ \\
\hline $\mathrm{NO}(\mu \mathrm{mole})$ & $10.59 \pm 0.29$ & $10.88 \pm 0.41^{*}$ & $12.59 \pm 0.29$ & $10.92 \pm 0.41+$ \\
\hline TBARS $(\mu \mathrm{mol} / \mathrm{mg}$ & $6.44 \pm 0.21$ & $6.53 \pm 0.25^{*}$ & $11.31 \pm 0.85$ & $8.44 \pm 0.32+$ \\
\hline
\end{tabular}

Results are expressed as mean \pm SD of mice $(n=10)$. ${ }^{*}$ Significant $(\mathrm{p}>0.05)$ compared to normal control group. + Significant $(p>0.05)$ compared to tumor- bearing group 
Table 3: Mean and standard deviation of SOD and GPX activities as well as MDA and GSH contents in erythrocytes of different groups studied.

\begin{tabular}{|l|l|l|l|l|}
\hline Parameter & $\begin{array}{l}\text { Control } \\
\text { (healthy mice) }\end{array}$ & $\begin{array}{l}{\left[\mathbf{C u L}(\mathbf{O H})\left(\mathbf{C l O}_{4}\right)\right]-} \\
\text { treated mice }\end{array}$ & $\begin{array}{l}\text { EAC bearing } \\
\text { mice }\end{array}$ & $\begin{array}{l}{\left[\mathbf{C u L}(\mathbf{O H})\left(\mathbf{C l O}_{4}\right)\right]} \\
\text {-treated EAC } \\
\text { bearing mice }\end{array}$ \\
\hline SOD(U/g.Hb) & $408.80 \pm 2.00$ & $435.27 \pm 2.15^{*}$ & $361.76 \pm 1.34$ & $530.97 \pm 0.98+$ \\
\hline GPX $(\mathrm{U} / \mathrm{g} . \mathrm{Hb})$ & $35.51 \pm 0.65$ & $48.44 \pm 0.98^{*}$ & $28.00 \pm 1.12$ & $54.88 \pm 0.87+$ \\
\hline $\mathrm{GSH}(\mu \mathrm{mol} / \mathrm{g} . \mathrm{Hb})$ & $6.01 \pm 0.28$ & $7.20 \pm 0.81^{*}$ & $3.11 \pm 0.17$ & $7.14 \pm 0.18+$ \\
\hline TBARS $(\mu \mathrm{mol} / \mathrm{g}$. & $4.25 \pm 0.27$ & $5.53 \pm 0.32^{*}$ & $10.69 \pm 0.33$ & $7.44 \pm 0.32+$ \\
\hline
\end{tabular}

Results are expressed as mean \pm SD of mice $(\mathrm{n}=10) .{ }^{*}$ Significant $(\mathrm{p}<0.05)$ compared to normal control group. + Significant $(p>0.05)$ compared to tumor- bearing group

\section{DISCUSSION}

Cancer is a pathological state involving uncontrolled proliferation of tumor cells (Psomas et al., 2006) ${ }^{(29)}$. The present study demonstrated that $\mathrm{Cu}$ complex markedly reduced the growth of Ehrlich ascites carcinoma cells. This is evident from decreased cell viability and increased survival time of mice treated daily with $\mathrm{CuL}(\mathrm{OH})\left(\mathrm{ClO}_{4}\right)$ complex. The present investigation revealed that ALT and AST activities exhibited a significant decrease in EAC group treated with $\mathrm{Cu}$ complex compared to untreated EAC mice group. Creatinine level exhibited a significant increase in EAC group treated with $\mathrm{Cu}$ complex compared to untreated EAC mice group. These results are in agreement with those of Khanam et al. (1997) $^{(\mathbf{3 0})}$. $\mathrm{CuL}(\mathrm{OH})\left(\mathrm{ClO}_{4}\right)$ treatment of EAC tumor bearing mice also restored ALT and AST levels to almost normal values and thereby rescued them from liver failure.

The concurrent study revealed that TBARS levels in both liver homogenate and erythrocyte lysate and hepatic NO exhibited significant decrease in EAC group treated with $\mathrm{Cu}$ complex compared to EAC group without treatment. These results are in agreement with those of kern and kehrer (2005) ${ }^{\mathbf{( 3 1 )}}$. Interestingly, the present work showed that the activity of SOD, GPX and as well as the level of GSH in both liver homogenates and erythrocytes were decreased in EAC group treated with $\mathrm{Cu}$ complex compared to EAC group without treatment and this finding is comparable to that of Qiao et al. $\mathbf{( 2 0 1 1 )}^{(\mathbf{3 2})}$. So, it could be suggested that the studied $\mathrm{Cu}$ complex modulates SOD and GPX to reduce oxidative stress in liver and erythrocytes. Therefore, the present finding, in part, is consistent with the suggestion that $\mathrm{Cu}$ complex might induce apoptosis as evidenced by decreased EAC cells viability and increased survival time of mice might suggest the delaying impact of $\mathrm{Cu}$ complex on cell division (Tripathi, et al. 2007) ${ }^{(33)}$. 
The present flow cytometric study supported these findings and showed that $\mathrm{Cu}$ complex not only retarded EAC cells growth by delaying their progression from G0/G1 to the DNA synthetic phase of the cell cycle but also significantly slowed DNA synthesis during the cell cycle in $\mathrm{Cu}$ complex treated mice as compared with that in untreated mice. These results are in accordance with those of other investigators (Elo, 2004) $^{(\mathbf{3 4})}$. Furthermore, the DNA index, which is the ratio of abnormal to normal cellular DNA, indicated a decrease in the aneuploidy status of EAC cells obtained from mice treated with $\mathrm{Cu}$ complex (Fig.4). Considering these cell cycle results with reduced viability and increased SOD, GPX and GSH levels, it appears that $\mathrm{Cu}$ complex might produce apoptotic cells which might be phagocytosed either by macrophages or by adjacent viable cells (Osinsky et al., 2004) ${ }^{(\mathbf{3 5})}$. It could also, be concluded that in addition to the direct effect of $\mathrm{Cu}$ complex on specific receptors in tumor cells (Iakovidis et al., 2011) ${ }^{(\mathbf{3 6})}, \mathrm{Cu}$ complex $\left[\mathrm{CuL}(\mathrm{OH})\left(\mathrm{ClO}_{4}\right)\right]$ can induce, in apart, apoptosis of EAC cells and phase delay of the cell cycle.

\section{REFERENCES}

1. Anand P, Kunnumakkara AB, Sundaram C, Harikumar KB, Tharakan ST, Lai OS, Sung B, Aggarwal BB. (2008): Cancer is a preventable disease that requires major lifestyle changes. Pharm. Res., 25 (9): 2097-116.
2. Valko, M., Rhodes, C.J., Moncol, J., Izakovic, M.and Mazur, M. (2006): Free radicals, metals and antioxidants in oxidative stress-induced cancer. Chem Biol Interact., 160 (1):1-40.

3. Valko, M.; Morris, H.; Cronin, M.T.D. (2005): Metals, toxicity and oxidative stress, Curr. Med. Chem., 12 (10):1161-1208.

4. Lecour, S., Merwe, E.V., Opie, L.H. and Sack, M.N. (2006): Ceramide attenuates hypoxic cell death via reactive oxygen species signaling. J. Cardiovasc. Pharmacol., 47(1): 158-63.

5. Cesaratto, L., Vascotto, C., Calligaris, S.and Tell, G. (2004): The importance of redox state in liver damage. Ann. Hepatol., 3(3):86-92.

6. KC, S., Cárcamo, J.M. and Golde, D.W. (2006): Antioxidants prevent oxidative DNA damage and cellular transformation elicited by the over-expression of c-MYC. Mutat. Res ., 593(1-2):64-79.

7. Barondeau, D.P.; Kassmann, C.J.; Bruns, C.K.; Tainer, J.A. and Getzoff, E.D. (2004): Nickel superoxide dismutase structure and mechanism. Biochemistry 43(25): 8038-8047.

8. Landis, G.N. and Tower, J. (2005): Superoxide dismutase evolution and life span regulation. Mech. Ageing Dev., 126(3): 365379.

9. Behrend, L.; Henderson, G. and Zwacka, R.M. (2003): Reactive oxygen species in oncogenic transformation. 
Biochem. Soc. Trans., 31(Pt. 6): 1441-1444.

10. Wang, Y., Zhang, X., Zhang, Q. Yang, Z. (2010): Oxidative damage to DNA by 1,10 phenanthroline/L-threonine copper (II) complexes with chlorogenic acid. BioMetals 23(2), 265-273.

11. Sies, H. (1997): Oxidative stress: oxidants and antioxidants. Exp. Physiol., 82 (2): 291-5

12. Suntres ZE and Lui, EM (2006): Prooxidative effect of copper-metallothionein in the acute cytotoxicity of hydrogen peroxide in Ehrlich ascents tumor cells. Toxicology 217(2-3): 155168.

13. Brewer GJ (2009): The risks of copper toxicity contributing to cognitive decline in the aging population and to Alzheimer's disease. J. Am. Coll. Nutr., 28(3): 238-42.

14. Daniel, K.G.; Harbach, R.H.; Guida, W.C. and Dou, Q.P. (2004): Copper storage diseases: Menkes, Wilson's, and cancer. Front. Biosci., 9:2652-2662.

15. Bonham, M., O'Connor, J.M., Hannigan, B.M. Strain, J.J. (2002): The immune system as a physiological indicator of marginal copper status?. Br. J. Nutr., 87(5): 393-403.

16. Tisato, F., Marzano, C., Porchia, M. Pellei, M, Santini, C. (2010): Copper in diseases and treatments, and copper-based anticancer strategies. Medicinal Research Reviews 30(4): 708749.

17. El-Saied, F. A., Ayad, M.I., Issa, R.M. and Aly, S. A.
(2000): Synthesis and characterization of Iron (III), Cobalt (II), Nickel (II) and Copper (II) Complexes of 4formylazomalononitrile antipyrine. Polish J.Chem.,74 (7):919- 926.

18. Boyse, E., Old, E., Chouroubnkov, I. (1964): Cytotoxic test of determination of mouse antibody, in: M. Eitsen (Edition), Methods in Medical Research. Vol. I, Year Book Medical Publishers, Chicago, IL, pp. 39-40.

19. Tapiero, H., Townsend, D.M. Tew, K.D. (2003): Trace elements in human physiology and pathology: Copper. Biomedicine and Pharmacotherapy, 57(9):386-398.

20. Beutler E; Duron O, Kelly MB (1963): Improved method for the determination of blood glutathione. J. Lab. Clin Med., 61: $882-888$.

21. Beutler, E. (1975): Red cell metabolism -a manual of biochemical methods, $2^{\text {nd }}$ edition, Grune and Straton, (Publisher), New York, pp 69-72.

22. Nishikimi M, Appaji N, Yang K (1972): The occurrence of superoxide anion in the reaction of reduced phenazine methosulphate and molecular oxygen. Biochem .Biophys. Res. Commun., 46(2): 844-853.

23. Schmidt, H.H (1995): Colorimetric aqssay for nitric oxide determination. Biochemica 2:22-23.

24. Satoh, K. (1978): Serum lipid peroxide in cerebrovascular disorders determined by a new 
colorimetric method.. Clinica. Chimica. Acta 90(1): 37.

25. Lowry O, Rosebrough $\mathbf{N}$, Fare A, Randall $R$ (1951): Protein measurement with the Folin phenol reagent. J. Biol. Chem., 193(1): 165: 175.

26. Wintrobe, M.M., Lee, G.R., Boggs, D.R., Athens, J.W., and Foerster, J. (1965): Clinical Hematology. Lea and Febiger $17^{\text {th }}$ Edition,. p. 1272.

27. Baisch H, Göhde W, Linden WA. (1975): Analysis of PCR data to determine the fraction of cells in the various phases of cell cycle. Radiat. Environ. Biophys., 12(1): 31-39.

28. Murry, R.S. (1982): Schaum`s outline series of theory and problems of probability and statistics, Singapore, McGrawHill Book Company, vol., 8: pp 265-298.

29. Psomas, G. Tarushi, A. Efthimiadou, E.K. Sanakis, Y. Raptopoulou, C.P. Katsaros, N. (2006): Synthesis, structure and biological activity of copper (II) complexes with oxolinic acid. J. Inorg. Biochem., 100(11): 1764 1773.

30. Khanam, J.A., Bag, S.P., Sur. B. and Sur, P. (1997): Antineoplastic activity of copper -benzhydroxamic acid complex against Ehrlich ascites carcinoma (EAC) in mice. Ind. J.Pharmacol., 29: 157-161.

31. Kern, J.C. Kehrer, J.P. (2005): Free radicals and apoptosis: relationships with glutathione, thioredoxin and the BCL family of proteins. Front. Biosci., 10: $1727-38$

32. Qiao, X. Ma, Z. Y. Xie, C.Z. (2011): Study on potential antitumor mechanism of a novel Schiff Base copper (II) complex: synthesis, crystal structure, DNA binding, cytotoxicity and apoptosis induction activity. J. Inorg. Biochem., 105(5): 728737.

33. Tripathi, L. Kumar, P. Singhai, A.K. (2007): Role of chelates in treatment of cancer. Ind.J.Cancer 44(2): $62-71$.

34. Elo, H. (2004): he antiproliferative agents trans- bis (resorcylaldoximato) copper (II) and trans-bis $(2,3,4-$ trihydroxybenzaldoximato) copper(II) and cytopathic effects of HIV. Zeitschrift für Naturforschung, 59(7-8): 609611.

35. Osinsky S, Levitin I, Bubnovsk aya $L$, Sigan A, Ganusevich I, K ovelskaya AV

alkovskaya $\mathbf{N}$, Campanella $\mathrm{L}, \mathbf{W}$ ardman P. (2004): Selectivity of effects of redox-active cobalt (III) complexes on tumor tissue. Exp. Oncol., 26(2):140-4.

36. Iakovidis, I., Delimaris,I. Piperakis, S.M.(2011): Copper and Its complexes in medicine: a biochemical approach. Mol. Biol. Intern., 2011: 1-13. 


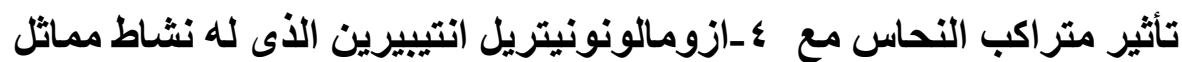 لإنزيم السوبر أكسيد ديسميوتيز على خلايا ايرلش السرطانية فئرئ في الفئران
}

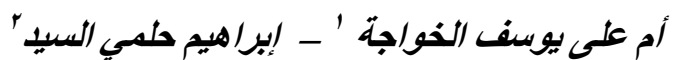

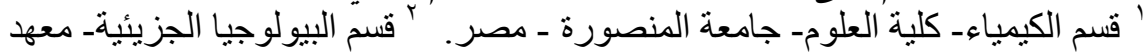 \\ بحوث الهنسة الور اثية و التكنولوجيا الحيوية - جامعة المنوفية ـ مصر.
}

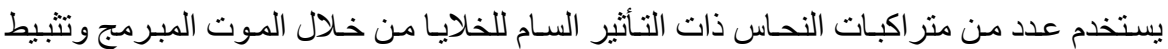

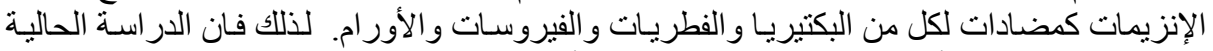

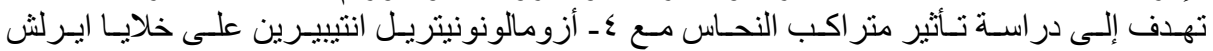

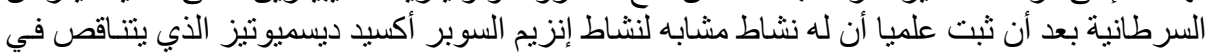

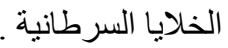

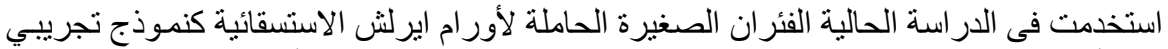

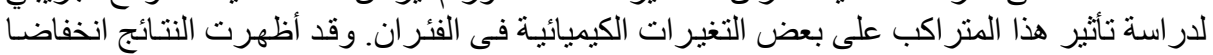

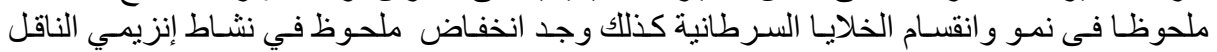

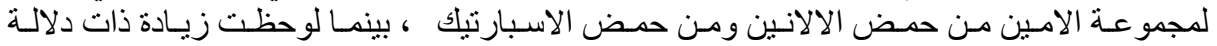

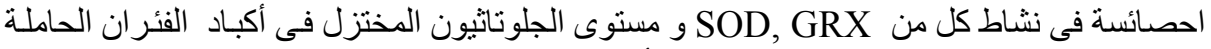

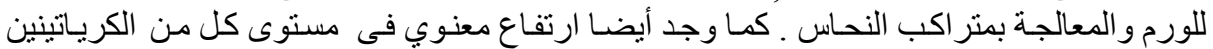

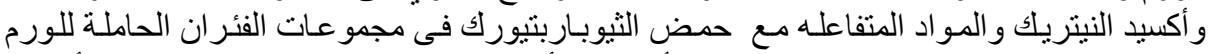

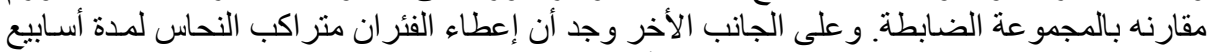

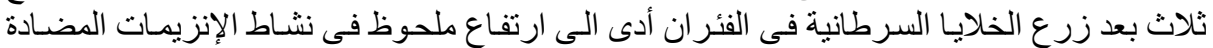

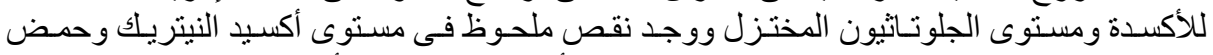

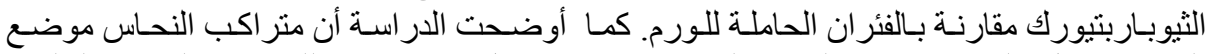

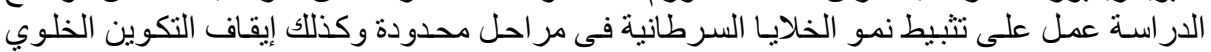

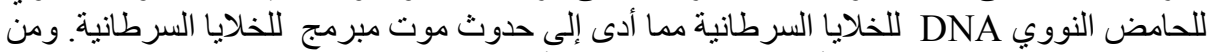

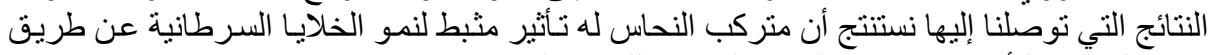
تثبيط التكسير التأكسدى وتحفيز الموت المبرمج للخلايا السرطانية. 